\title{
Torrefaction of Short Rotation Coppice of Poplar under Oxidative and Non-Oxidative Atmospheres ${ }^{\dagger}$
}

\author{
Ana Álvarez, Gemma Gutiérrez, María Matos, Consuelo Pizarro * and Julio L. Bueno \\ Department of Chemical and Environmental Engineering, Faculty of Chemistry, University of Oviedo, \\ Julián Clavería 8, 33006 Oviedo, Spain; anaabres@gmail.com (A.Á.); gutierrezgemma@uniovi.es (G.G.); \\ matosmaria@uniovi.es (M.M.); jlbueno@uniovi.es (J.L.B.) \\ * Correspondence: pizarroconsuelo@uniovi.es; Tel.: +34-985-103438 \\ + Presented at the 2nd International Research Conference on Sustainable Energy, Engineering, Materials and \\ Environment (IRCSEEME), Mieres, Spain, 25-27 July 2018.
}

Published: 1 November 2018

\begin{abstract}
Torrefaction improves some of the poorest characteristics of biomass such as hygroscopicity, low energy density, or poor grindability which may cause some problems during its handling, storage and combustion. The aim of this work is to apply the torrefaction process to a Short Rotation Coppice of Poplar (SRCP) and characterize the new fuel. Therefore, both non-oxidative and oxidative torrefaction of SRCP were conducted in a tube furnace reactor within the range $200-240{ }^{\circ} \mathrm{C}$ and the torrefied biomass was fully characterize, i.e., proximate, ultimate, compositional and heating value analysis as well as wettability studies. In addition, Pyrolysis-Gas Chromatography/Mass Spectrometry (Py-GC/MS) was performed at optimal torrefaction temperature. Torrefaction kinetics were obtained using a thermogravimetric analyzer at optimal torrefaction temperature. Minimum mass and energy yields were found to be respectively $85.0 \%$ and $87.4 \%$ for oxidative torrefaction and $87.5 \%$ and $94.1 \%$ for non-oxidative option. Moisture was reduced from $6.97 \%$ to $4.8 \%$ and $4.4 \%$ for oxidative and non-oxidative torrefaction, respectively. Wettability studies carried out show an increase in hydrophobic behavior. Lignin was affected by torrefaction since decomposition products from guaiacyl $(\mathrm{G})$ and syringyl (S) units were released during Py-GC/MS experiments. The reaction orders were 1.92 and 1.82 for oxidative and non-oxidative torrefaction, respectively and kinetic constant values were $5.99 \cdot \times 10^{-5}$ and $2.98 \cdot \times 10^{-5} \mathrm{~s}^{-1}$.
\end{abstract}

Keywords: torrefaction; Py-GC/MS; hydrophobicity; torrefaction kinetics

\section{Introduction}

Torrefaction is an endothermic gas-solid reaction and it is usually carried out under non-oxidative or low oxygen atmospheres. However, torrefaction can occur under air atmosphere named oxidative torrefaction.

Increase of energy density, hydrophobic behavior and improvement of grindability are some of the benefits of torrefied biomass compared to raw biomass. These changes improve the handling, storage and combustion processes of biomass. In addition, the degradation of the torrefied biomass is minimized because the resistance to biological activity is increased. Another advantage of torrefaction is that a wide variety of raw biomass types can be used and the final properties depend on the torrefaction conditions [1].

Torrefied biomass or torrefied biomass together with other fossil fuels is used in numerous energy industries. It can be applied both for electrical uses and for thermal uses. The first refers to the generation of electric power, either with cogeneration systems or co-combustion systems. It is 
also possible to use biochar as a substitute for coke in blast furnaces. The second refers to thermal energy for heating, hot water supply or in industrial processes.

In the paper industry, non-renewable energy sources were partially or totally replaced by torrefied biomass. In the iron and steel industry, the use of torrefied biomass takes place in injection furnaces where it can completely replace the introduction of pulverized coal, without affecting the efficiency of the boiler. In the cement sector, a combination of torrefied biomass with coal in co-combustion furnaces is used [1,2].

On the contrary, in petrochemical industry the use of torrefied biomass is not yet sufficiently established to assert its success, although there are studies that recognize its use in obtaining engineering thermoplastics, such as the polyamide 6.6 [3].

\section{Materials and Methods}

Shor Rotation Coppice of Poplar (SRCP) was collected from experimental trial established on abandoned mining land. Biomass samples were grinded and sieved to a size between 710-1000 $\mu \mathrm{m}$.

Oxidative and non-oxidative torrefaction experiments were carried out in a tube furnace reactor at five different temperatures within the range of $200-240{ }^{\circ} \mathrm{C}$, every $10^{\circ} \mathrm{C}$. Air was used as oxidative atmosphere, while nitrogen was selected as inert atmosphere. The torrefaction temperature was held for $20 \mathrm{~min}$ and the flux of oxidizing or inert gas was set to $1 \mathrm{~L} / \mathrm{min}$.

Proximate analysis and heating value were carried out according to the ASTM Standards [4-7] in a muffle furnace, while ultimate analysis was conducted using an elemental analyzer. In compositional analysis, lignin, holocellulose and cellulose were quantified according to NREL procedure, ASTM D1104 standard and TAPPI T212 standard, respectively [8-10].

Released gases at optimal torrefaction temperature and inert atmosphere was characterized using pyrolysis gas chromatography/mass spectrometry (Py-GC/MS). For this assay, a micro-furnace type double-shot pyrolyzer attached to a GC/MS system Agilent 6890 was used. Samples $(4 \mathrm{mg}$ ) were placed in small crucible capsules and introduced in a pre-heated furnace (at optimal torrefaction temperature) in the absence of oxygen. The sample was kept for $2 \mathrm{~min}$ at this temperature before the evolved gases where directly injected in the GC/MS for analysis, see [11] for complete description of the method used.

For kinetic study, $4 \mathrm{mg}$ of the sample were subjected to thermal decomposition at optimal torrefaction temperature, using $200 \mathrm{~mL} \mathrm{~min}^{-1}$ of $\mathrm{N}_{2}$ as carrier gas and the temperature program described by Chen and Kuo [12].

\section{Results and Discussion}

\subsection{Optimal Torrefaction Temperature}

Firstly, the optimal temperature of torrefaction was determined from mass and energy yields of torrefied biomass obtained at different torrefaction conditions. Mass and energy yields were in the range between $85.0-93.0 \%$ and $87.4-93.1 \%$ respectively for oxidative torrefaction and $87.5-94.0 \%$ and $94.1-97.2 \%$ for non-oxidative torrefaction. It is widely accepted that the optimal balance of mass and energy for biomass torrefaction is $80 \%$ of mass yield and $90 \%$ of energy yield in the torrefied biomass [13]. However, since at temperatures higher than $240^{\circ} \mathrm{C}$ the sample could be carbonized, the optimal torrefaction temperature for SRCP was set to be $230^{\circ} \mathrm{C}$ to avoid carbonization.

\subsection{Proximate, Ultimate, Compositional and Kinetic Analysis}

The moisture content decreases as the torrefaction temperature increases and at the optimal temperature, this value is 4.8 and $4.4 \%$ for oxidative and non-oxidative torrefaction, respectively (Figure 1). 


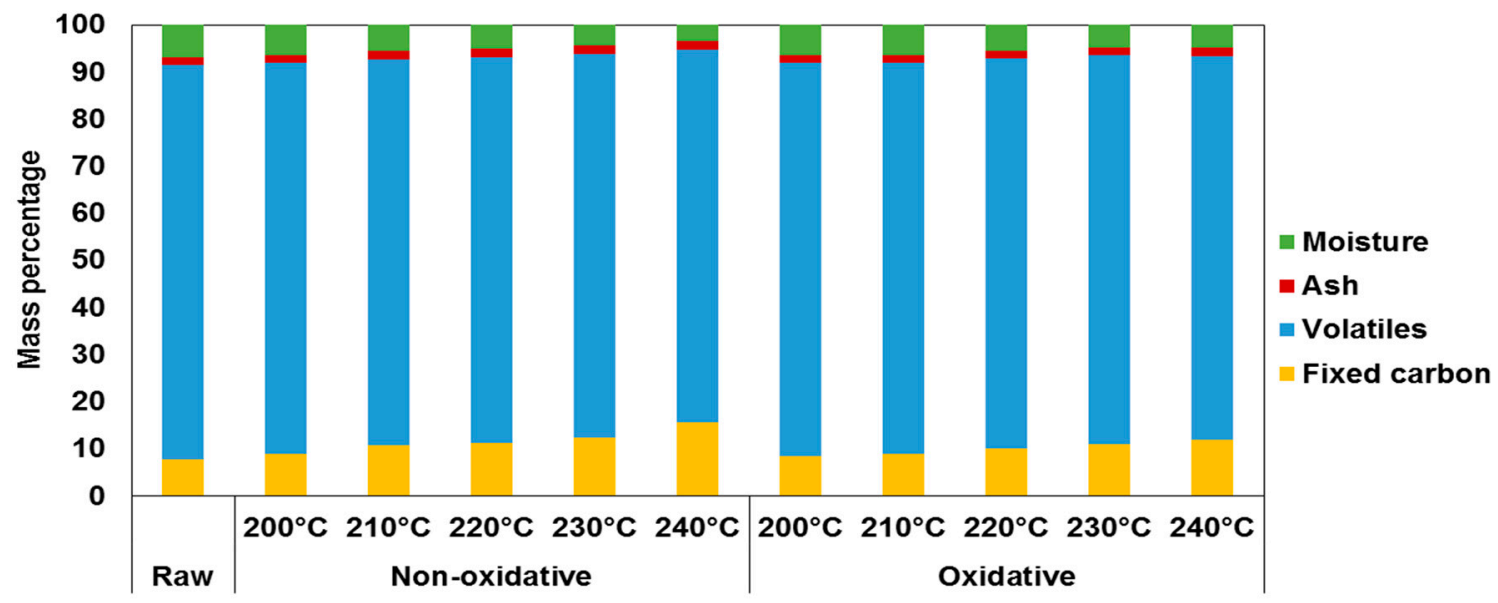

Figure 1. Proximate analysis of torrefied SRCP.

The atomic $\mathrm{O} / \mathrm{C}$ and $\mathrm{H} / \mathrm{C}$ ratios decrease as the torrefaction conditions become more severe. Regarding the compositional analysis, holocellulose decreased while percentage of lignin in torrefied SRCP increased. Torrefaction kinetics of oxidative and non-oxidative processes were depicted on Table 1.

Table 1. Kinetic parameters of oxidative and non-oxidative torrefaction.

\begin{tabular}{ccc}
\hline Sample & $\mathbf{k ~}^{\left(\mathbf{s}^{-1}\right)}$ & $\boldsymbol{n}$ \\
\hline Oxidatively torrefied SRCP & $5.99 \cdot \times 10^{-5}$ & 1.92 \\
Non-oxidatively torrefied SRCP & $2.98 \times \times 10^{-5}$ & 1.82 \\
\hline
\end{tabular}

\subsection{Hydrophbicity and Contact Angle}

The contact angle measurements showed that there was an increase of hydrophobicity due to the increase of contact angle (Table 2). The values obtained ranged from $79.7^{\circ}$ for raw SRCP (with no torrefaction treatment) till $104.4^{\circ}$ and $102.1^{\circ}$ obtained with the samples torrefied at $240{ }^{\circ} \mathrm{C}$ for oxidative and non-oxidative torrefaction, respectively.

Table 2. Contact angle measurements for SRCP samples.

\begin{tabular}{ccc}
\hline Sample & Oxidative & Non-Oxidative \\
\hline Raw & \multicolumn{2}{c}{79.7} \\
200 & 98.6 & 88.4 \\
210 & 103.7 & 93.8 \\
220 & 104.1 & 96.3 \\
230 & 103.9 & 98.2 \\
240 & 104.4 & 102.1 \\
\hline
\end{tabular}

\subsection{Py-GC/MS}

The main compounds released at optimal temperature were conipheryl aldehyde and synapaldehyde. Family compounds are shown on Table 3. The amount of lignin derived compounds released is higher than sugar-derived fraction. However, it must be taken into account the conditions of the experiment, since $\mathrm{CO}_{2}$ or acetic acid were not identified due to those conditions. 
Table 3. Released gases of SRCP at optimal temperature from Py-GC/MS as percentage of total chromatographic area.

\begin{tabular}{cc}
\hline Type of Compound & $\%$ \\
\hline Aromatic & 2.51 \\
Lignin (G) & 29.76 \\
Lignin (S) & 37.82 \\
Lipid & 6.79 \\
Sugars and sugar-derived products & 15.46 \\
Sterols & 2.13 \\
\hline
\end{tabular}

Author Contributions: J.L.B. and C.P. conceived and designed the experiments; G.G., M.M. and A.Á. performed the experiments; J.L.B., C.P., G.G., M.M. and A.Á. analyzed the data; G.G. M.M. and A.Á. contributed reagents/materials/analysis tools; A.Á. wrote the paper.

Funding: This research was funded by MINECO for the economic support given to the Normalized vegetable Biomass for Efficient Energetic Trigeneration project (MINECO-13-CTQ2013-45155-R) and Consejería de Economía y Empleo del Principado de Asturias for the economic support given to the TRIBIONOR project (PCTI Asturias 2013-2017, Ref. FC-15-GRUPIN14-095), which makes the continuation of research in this field possible. A. Álvarez acknowledges receipt of a graduate fellowship from the Severo Ochoa Program (Principado de Asturias, Spain).

Conflicts of Interest: The authors declare no conflict of interest. The founding sponsors had no role in the design of the study; in the collection, analyses, or interpretation of data; in the writing of the manuscript, and in the decision to publish the results.

\section{References}

1. Proskurina, S.; Heinimö, J.; Schipfer, F.; Vakkilainen, E. Biomass for industrial applications: The role of torrefaction. Renew. Energy 2017, 111, 265-274. doi:10.1016/j.renene.2017.04.015.

2. Gent, S.; Twedt, M.; Gerometta, C.; Almberg, E. Theoretical and Applied Aspects of Biomass Torrefaction: For Biofuels and Value-Added Products; Butterworth-Heinemann: Oxford, UK; Cambridge, MA, USA, 2017.

3. Vold, J.; Ulven, C. Torrefied-biomass-filled polyamide biocomposites. In Lignocellulosic Fibre and Biomass-Based Composite Materials; Elsevier: Amsterdam, The Netherlands, 2017; pp. 423-445, doi:10.1016/B978-0-08-100959-8.00020-2.

4. ASTM D1102-84. Standard Test Method for Ash in Wood; ASTM International: West Conshohocken, PA, USA, 2013.

5. ASTM E711-87. Standard Test Method for Gross Calorific Value of Refuse-Derived Fuel by the Bomb Calorimeter (Withdrawn 2004); ASTM International: West Conshohocken, PA, USA, 1987.

6. ASTM E871-82. Standard Test Method for Moisture Analysis of Particulate Wood Fuels; ASTM International: West Conshohocken, PA, USA, 2013.

7. ASTM E872-82. Standard Test Method for Volatile Mater in the Analysis of Particulate Wood Fuels; ASTM International: West Conshohocken, PA, USA, 2013.

8. ASTM D1104-56. Method of Test for Holocellulose in Wood (Withdrawn 1985); ASTM International: West Conshohocken, PA, USA, 1978.

9. Sluiter, A.; Hames, B.; Ruiz, R.; Scarlata, C.; Sluiter, J.; Templeton, D.; Crocker, D. Determination of Structural Carbohydrates and Lignin in Biomass: Laboratory Analytical Procedure (LAP); Revised August 2012; National Renewable Energy Laboratory: Golden, CO, USA, 2008.

10. TAPPI. TAPPI T 212-One Percent Sodium Hydroxide Solubility of Wood and Pulp, 12th ed.; TAPPI: Atlanta, GA, USA 2012.

11. Álvarez, A.; Nogueiro, D.; Pizarro, C.; Matos, M.; Bueno, J.L. Non-oxidative torrefaction of biomass to enhance its fuel properties. Energy 2018, 158, 1-8, doi:10.1016/j.energy.2018.06.009. 
12. Chen, W.-H.; Kuo, P.-C. Isothermal torrefaction kinetics of hemicellulose, cellulose, lignin and xylan using thermogravimetric analysis. Energy 2011, 36, 6451-6460, doi:10.1016/j.energy.2011.09.022.

13. Agarwal, A.K.; Pandey, A.; Gupta, A.K.; Aggarwal, S.K.; Kushari, A. Novel Combustion Concepts for Sustainable Energy Development, 1st ed.; Springer: New Delhi, India, 2014.

(c)

(C) 2018 by the authors. Licensee MDPI, Basel, Switzerland. This article is an open access article distributed under the terms and conditions of the Creative Commons Attribution (CC BY) license (http://creativecommons.org/licenses/by/4.0/). 